\title{
"Nothing in This World Is Indifferent to Us" \\ The Primacy of Encounter and the Intersubjectivity of Nature
}

\author{
Anna Robertson \\ Master of Theological Studies, 2016 \\ Boston College School of Theology and Ministry
}

"We're moving from one plane of reality to another," writes author and activist Terry Tempest Williams, "and what is required of us is spiritual."1

When I was a girl, maybe seven or eight, I was riding with my mother in the car during a rainstorm. We passed an elderly woman, walking with arms full of groceries, getting drenched, and my mother decided we would give her a ride. From the back seat, I listened with a growing and new sense of dread as, for the next ten minutes, the woman prophesied about the end of the world. I do not recall exactly how she described it, but I do remember that it was coming, and that I was terrified. It was the first time that I had experienced the idea of the world that contained my entire existence ceasing to be. For the next year, I obsessed over this impending end. Eventually I noticed that days, and then weeks, would go by without me thinking about it, until I would hear some talk of this or that doomsday prophesy, and I would begin again the furtive work of repression.

The birth of a kind of apocalyptic consciousness in me as a child is not unlike the current shocks to our collective consciousness. Just as the thought of my world ceasing to exist occurred to me as jarring and new, so too the lack of certainty that future generations will continue to experience the world as we have experienced it registers on the collective consciousness as a novel shock. Joanna Macy calls this loss of certainty "the pivotal psychological reality of our

\footnotetext{
${ }^{1}$ Terry Tempest Williams, interview by Sarah van Gelder, “Terry Tempest Williams: 'Survival Becomes a Spiritual Practice,"” Yes! Magazine, October 5, 2015.
} 
time." She writes, "As a society we are caught between a sense of impending apocalypse and the fear of acknowledging it." ${ }^{3}$ We continue to go about our daily lives, often in this part of the world ${ }^{4}$ as if we have four planets' worth of resources to sustain our lifestyles, all the while harboring in the backs of our minds what Macy calls "anguished awareness," amorphous and shadowy, "that our world could be extensively damaged at any moment."5

Macy closes her essay with the question that I pose tonight: "Can we sustain our gaze upon the prospects of ecological holocaust without becoming paralyzed with fear or grief? Can we acknowledge and live with our pain for the world in ways that affirm our existence and release our power to act?"' If we are indeed, as Tempest Williams suggests, in a process of spiritual transition from one plane of reality to another, the task before us as theologians and ministers is to grapple specifically with the question of what kind of spirituality fosters this transition. What spiritual practices can ground a sustained "gaze upon the prospects of ecological holocaust" accompanied by an authentic hope? Tonight, I will propose one such practice, but I also want to entreat everyone present to continue thinking theologically with me about this question of how to live life as if we only have this one planet - because we do, indeed, only have this one planet, and we have, indeed, plundered it greatly.

\footnotetext{
2 Joanna Macy, "Working Through Environmental Despair," in Ecopsychology: Restoring the Earth, Healing the Mind, ed. Theodore Roszak, Mary E. Gomes, and Allen D. Kanner (San Francisco: Sierra Club Books, 1995): 241.

${ }^{3}$ Ibid.

${ }^{4}$ This paper was given at a conference at Boston College School of Theology in Ministry, so "this part of the world" refers to the North American context, specifically that of people of sufficient privilege to be pursuing graduate studies.

${ }^{5}$ Macy, “Working Through Environmental Despair," 243.

${ }^{6}$ Ibid., 252.
} 
I am going to share a couple of "harrowing statistics," a genre in themselves in the climate change literature. However, I do not share these, which I borrow from Pope Francis's recent encyclical Laudato si, as "proof" of our crisis, nor in the hopes that these figures in themselves will spur action. Rather, I invite you to take note, to truly pay attention, to your interior reception of them. How do these statistics land upon your heart of hearts?

If present trends continue, this century may witness extraordinary climate change and an unprecedented destruction of ecosystems, with serious consequences for all of us. A rise in the sea level, for example, can create extremely serious situations, if we consider that a quarter of the world's population lives on the coast or nearby, and that the majority of our megacities are situated in coastal areas. $^{7}$

Some studies warn that an acute water shortage may occur within a few decades unless urgent action is taken. The environmental repercussions could affect billions of people; it is also conceivable that the control of water by large multinational businesses may become a major source of conflict in this century. ${ }^{8}$

From anxiety to anguish, terror to rage, guilt to sorrow, we experience a range of uncomfortable emotions when we confront reality honestly. ${ }^{9}$ However, Pope Francis reminds us in Laudato si that we are called to make just such a confrontation, pointing toward the deleterious consequences of choosing to avoid an honest confrontation with reality. He writes that it is through "trying not to see them, trying not to acknowledge them, delaying the important

\footnotetext{
${ }^{7}$ Francis, Laudato si, Encyclical Letter, Vatican Website, May 24, 2015. http://www.vatican.va/content/francesco/ en/encyclicals/documents/papa-francesco_20150524_enciclica-laudato-si.html, sec. 24.

${ }^{8}$ Ibid., 31 .

${ }^{9}$ Joanna Macy identifies rage, sorrow, and guilt as three typical responses to the enormity of the climate crises (Macy, "Working Through Environmental Despair," 241). Separately, Robert Jensen identifies anguish and anxiety as perfectly rational reactions which need not be repressed but worked through honestly (Robert Jensen, "Get Apocalyptic: Why Radical Is the New Normal," Yes! Magazine, May 24, 2013).
} 
decisions and pretending that nothing will happen" that "human beings contrive to feed their self-destructive vices." 10

In Laudato si, Pope Francis calls us to "a new and universal solidarity"11 and "to become painfully aware, to dare to turn what is happening to the world into our own personal suffering and thus to discover what each of us can do about it." ${ }^{12}$ In short, Francis calls us to conversion, so that our hearts and actions align with the reality of our interrelatedness, the reality that "[n]othing in the world is indifferent to us." ${ }^{13}$ For Francis, this conversion moves away from a throwaway culture, individualism, and "misguided anthropocentrism"14 toward "disinterested concern for others," "the rejection of every form of self-centeredness and self-absorption," 15 and "a generous and worthy creativity which brings out the best in humans." 16 In the following pages, I examine the potential of Jon Sobrino's theology of encounter and mercy to inform an understanding of the importance of encountering the natural world as a catalyst for conversion.

I have already argued that the task of theologians and ministers today is to articulate a new and renewed spirituality that takes the climate crises into account. Jon Sobrino writes that "spirituality is the spirit with which we confront the real." 17 This confrontation is not as simple

\footnotetext{
${ }^{10}$ Francis, Laudato $\mathrm{Si}, 59$.

11 Ibid., 14.

12 Ibid., 19.

${ }^{13}$ Francis, Laudato Si, 2.

14 Ibid., 118.

15 Ibid., 208.

${ }^{16}$ Ibid., 211.

17 Jon Sobrino, "Spirituality and the Following of Jesus," in Systematic Theology: Perspectives from Liberation Theology, ed. Jon Sobrino and Ignacio Ellacuría (Maryknoll: Orbis Books, 1996): 236.
} 
as merely absorbing the facts, for we live in a world that often seems to conspire against truthtelling and tend toward a kind of comfortable obfuscation. Sobrino thus writes that honesty before the real involves not only apprehending truth but responding adequately to it. Reality demands a "confrontation with our innate tendency to subordinate truth and to evade reality" 18 that is, I would argue, to overcome our own alienation, which keeps us from recognizing the other as intimately tied to ourselves. In fewer words, reality demands conversion.

Such conversion is risky business, for it also demands sizing up our own complicity in injustice and our failure to recognize the unique subjectivity of those around us. Furthermore, it can be heartbreaking, for in such honest encounters with the reality of suffering among our fellow human beings, we find ourselves , in a reaction of what Sobrino calls "mercy," suffering with the other. ${ }^{19}$ It is from the understandable desire to evade such suffering that the tendency toward anesthetization, which Macy identifies, arises. This is an anesthetic which we cannot localize, and so with our gaze turned away from the reality of suffering, so too "loves and losses are less intense, the sky is less vivid." ${ }^{20}$ However, the honest encounter with reality elicits a reaction of mercy, which arises out of a recognition of the fullness of the subjectivity of the other and compels a particular liberative praxis. Indeed, Sobrino suggests, our own subjectivity - our own full humanity - hinges upon mercy. It is "that in terms of which all dimensions of the

\footnotetext{
18 Ibid., 236.

19 Of mercy, Sobrino writes, “...this ethical practice of honesty is mercy or pity in confrontation with reality... Mercy denotes a reaction in the face of the suffering of another, which one has interiorized and which has become one and the same thing with oneself, with a view to saving that other" (Sobrino, "Spirituality and the Following of Jesus," 238).

20 Macy, “Working Through Environmental Despair,” 249.
} 
human being acquire meaning and without which nothing else attains to human status." ${ }^{21}$ Insofar as this honesty reconnects us with our capacity to experience not only pain but also joy, the encounter also energizes the hope for creative change.

What does this framework of honesty before the reality of the suffering other have to say with regard to the climate crises of our time? How might it inform our honest, repentant, mournful, hopeful, energized stance in the face of a very real kind of apocalypse - the end of the world as we know it? The framework depends on an understanding of intersubjectivity. The encounter is differentiated from the gaze by the degree to which the subjectivity of the other is recognized, and indeed the fullness of my own subjectivity depends on the extent to which I respond with mercy to the other as subject. The subject makes ethical claims on me, whereas I make utilitarian claims on the object. The subject uniquely reflects the image of God, whereas the object reflects and is contingent upon my own image. It is only in our profound alienation that we come to view others as objects. Francis refers to this alienation when he writes in Laudato si, "When human beings fail to find their true place in this world, they misunderstand themselves and end up acting against themselves." 22 What would an anthropology that considered the other-than-human as a subject in its own right look like?

Ecopsychologist Will Adams calls for "an interdisciplinary endeavor which aspires not only to understand our way of interrelating with nature but to transform it." ${ }^{23} \mathrm{He}$ calls us,

21 Sobrino, "Spirituality and the Following of Jesus," 238.

${ }^{22}$ Francis, Laudato si, 115.

23 Adams, "The Primacy of Interrelating," 25. 
furthermore, to a face-to-face relationship with the natural world, even as the opportunities for such encounters are dwindling as the planet writhes. He asks,

[W]hat might happen if we allow ourselves to interrelate with members of the natural community as unique and authentic others, as kindred subjects in a commonly shared world? What if we would openly participate in a face-to-face encounter with that deer who is eating the lilies in our garden, the maple tree in the park, the nearby mountain, or even the whole bioregional neighborhood of which we are participating members? And building upon such situated ethical encounters with uniquely singular others, how might we conceive and create greater compassion and justice in humankind's relationship with the other-thanhuman natural world? $?^{24}$

I will close with some simple thoughts on an experiment in reflecting on these sorts of encounters in my work with undergraduate students in campus ministry. In a small faith-sharing group, student leaders invited participants to spend a few moments reflecting on a particularly powerful encounter with the natural world. Participants were asked to recall an experience of wonder in nature and to remember how it felt to be a body encountering this natural other. One by one, students nostalgically shared their experiences of the exhilaration of climbing a volcano during a lightning storm, or the poignancy and sadness of returning to an old favorite green space in California to find it barren and brown. How might we sustain our gaze before the prospect of ecological demise while maintaining a hope in the God of surprises? To answer that question is the task before us as a theological community. But today, I suggest the tentative first steps of looking up at the leaves as you walk down Commonwealth Avenue or taking the time to make the thirty-minute walk to the trails of Hammond Pond Reservation, just beyond upper campus and then, the same way we share with others those stories of human encounter that ground our commitment to, for example, a preferential option for the poor, lifting up these stories of

\footnotetext{
24 Ibid., 36.
} 
encounter in community. In making space for the encounter and in allowing ourselves to be changed by it, we open ourselves to the grace of mutual transformation - and conversion. 


\section{Works Cited}

Adams, Will W. "The Primacy of Interrelating: Practicing Ecological Psychology with Buber, Levinas, and Merleau-Ponty." Journal of Phenomenological Psychology 38 (2007): 24-61. doi:10.1163/156916207X190238.

Francis. Laudato si. Encyclical Letter. Vatican Website. May 24, 2015. http://www.vatican.va/ content/francesco/en/encyclicals/documents/papa-francesco_20150524_enciclicalaudato-si.html.

Jensen, Robert. "Get Apocalyptic: Why Radical Is the New Normal.” Yes! Magazine, May 24, 2013.

Macy, Joanna. "Working Through Environmental Despair.” In Ecopsychology: Restoring the Earth, Healing the Mind, 240-61. Edited by Theodore Roszak, Mary E. Gomes, and Allen D. Kanner. San Francisco: Sierra Club Books, 1995.

Sobrino, Jon. "Spirituality and the Following of Jesus." In Systematic Theology: Perspectives from Liberation Theology, 233-56. Edited by Jon Sobrino and Ignacio Ellacuría. Maryknoll: Orbis Books, 1996.

Tempest Williams, Terry. "Terry Tempest Williams: 'Survival Becomes a Spiritual Practice.” By Sarah van Gelder. Yes! Magazine, October 5, 2015. 